\title{
Study on Multiple Cultivation Patterns of Teacher-to- be English Students
}

\author{
Yan Chen \\ Feixian College \\ Linyi University \\ Feixian, China
}

\begin{abstract}
To skillfully master certain teaching sills are what necessary for teacher-to-be students. Considering the status quo of English teaching which is weak in specific teaching cultivation and single in training form, this article tries to find a more logical cultivation pattern so as to meet the needs of social development.
\end{abstract}

Keywords-teacher-to-be English student; characteristics of English teaching; English teaching skills; multiple cultivation pattern

\section{INTRODUCTION}

Teachers are basic for a great education layout. To improve students' teaching level is an important point stated in Outline of National Medium and Long Term Program for Education Reform and Development (2010-2020). In coming teaching teams, teaching targeted English students are an important group for local colleges, as teacher-to-be students, their professional quality will influence a great number of young people, therefore, more attentions must be paid to cultivate their capabilities in major and teaching.

Based on the teaching skill cultivation modes of teacher-tobe English students in local colleges, status quo of teaching skill cultivation as well as characteristics of English teaching, this article raises a multiple cultivation modes specific and highly-applied teaching skills of teacher to-be students in local colleges.

\section{STATUS QUO}

Currently the deficiency of teacher-to-be students teaching skills cultivation is reflected on two points. 1. Less targeted. The position of English teaching skills in many local colleges is unclear, and the cultivation of teacher-to-be English students is still limited to the pedagogy + psychology + subject teaching approach + teaching practice model, after all, with only oneterm teaching method learning and one month practice, new teaches are difficult to meet the reform and development of basic English education and teaching. 2. Single form for training. Currently the training of teacher-to-be students in local colleges is rooted in theories, and teaching practice is limited to the one month in the final term, which will cause the separation of theory learning and practice, ultimately the students are unable to apply theoretical knowledge flexibly or solve actual problems in teaching, feeling hard to be competent for teaching after employment.

\section{Construction of Multiple Cultivation Mode of TEACHER-TO-BE STUDENTS}

\section{A. Classification of English Teaching Skills}

As a language, English can not only be used for communication but also as a cultural carrier. English teaching skills have uniqueness of their own, which are serial teaching conducts of teachers who apply professional knowledge and teaching theories to promote students to learn in class. Based on actual teaching, this article divides English teaching skills into four classifications: analyze students' recognition, take strategic instruction; select textbooks and make teaching design before class, class teaching, critical reflection after class and teaching research.

1) Analyze students characteristics in recognition, take strategic instruction.

During English learning, the language learning strategy may enable students to learn actively to improve the language level and get confident and further develop and improve their capabilities in communication. Therefore, with the characteristics of learners fully grasped, English teachers may instruct the students strategically in language learning so as to make the English teaching more targeted and further cultivate students' capabilities in English learning.

2) Select textbooks and make teaching design before class.

English teachers shall exert the humanities of English to enrich teaching contents through all kinds of language materials and expand students' vision. English teachers shall have certain sensibility in language, reject outdated textbooks and select the latest and suitable language materials for students to learn and design class activities as per teaching goals.

\section{3) Class teaching.}

Class teaching skills include questioning, arrangement and multimedia operation, yet the particularity of English raises higher requirements. During the class teaching, English teachers shall be able to arouse students' interest in English speaking so as to make the class interactive and enable students master the language through communication and interaction.

4) Critical reflection after class and teaching research.

Critical reflection is to double the original teaching concept and adopt new assumption to instruct practice. Through the 
critical reflection after class, teachers will clearly face the strength and deficiency of class teaching of their own, and conduct deep thinking of the problems so as to make theories and practice promote each other.

\section{B. Construction of Multiple Cultivation Modes of English Teacher-to-be students}

In order to cultivate applied and skilled English teachers, we should break through the single skills cultivation mode and make teacher-to-be students improve English teaching skills through connecting theories with practice on the basis of solid professional knowledge so that they will meet the needs of social development and satisfy the country and the people. This article raises a multiple cultivation mode applicable for English teacher-to-be students, which aims to gradually cultivate the students' teaching skills through infiltration layer by layer on the basis of perfect talent cultivation plan, it mainly includes the following:

\section{1) Perfect the talent cultivation plan of English teacher-to-} be students.

Talent cultivation plan is a basic instructive document for colleges to carry out the cultivation, before making the talent cultivation plan, colleges shall clarify the cultivation goals of English teacher-to-be students and establish targeted special cultivation plan.

\section{2) Connecting long term professional courses with English} teaching skills.

On cultivating teaching skills, we should change the previous mode where professional courses were separated from teaching, instead, we should integrate the cultivation of teaching skills to the learning of professional courses so as to achieve the win-win of learning of professional courses and cultivation of English teaching skills.

Class teaching skills are a practical knowledge, which are experiential knowledge based on circumstances, it is an imperceptible process with high operability, needing a long term accumulation in experience. Relying on the long term practical teaching instruction and training, English teacher-tobe students can better grasp how to carry out efficient and targeted class activities to cultivate one ability among listening, speaking and writing, how to clearly interpret knowledge, make it logical to interact with students so as to achieve the win-win of subject knowledge and teaching skills.

3) Connecting medium-term teaching theories with practice.

Long term cultivation makes teacher-to-be students carefully gasp teaching and four basic skills as listening, speaking, reading and writing, yet the medium term cultivation refers to several weeks of combined training aiming to not only intensify the students' theoretical basis but also make them access to primary and middle school class, more visually understanding of the primary and middle school students' needs of English learning.

4) Short term English teaching predominated by the second class activities.
The long term and medium term teaching skill training make the English teacher-to-be students get certain theoretical knowledge and experience accumulation in English teaching skills, besides, through critical reflection during the practice, the students can gradually find problems in English teaching skills, and problems are solved to improve their understanding of professional practice and finally rebuild knowledge and improve the teaching practice.

On one hand, according to the characteristics of tool and humanities, in order to make the English class more interactive, interesting and expanding, we can launch famous teacher teaching case analysis activities. In addition, according to the key points in English teaching, we can launch teaching matches such as grammar interpretation, listening and writing. Or other second class activities can be launched through teaching courseware match, microteaching match, inviting excellent primary and middle school teachers for lectures and so on so as to make the cultivation of English teaching skills more interesting and stir the enthusiasm and zeal of English teacherto-be students in teaching skill training. On the other hand, the short term second class activities will promote the students to form research-based teaching habits. For example, hold English teaching skill topic discussion to foster students' abilities of finding problems, analyzing problems and solving problems, encourage students to keep an eye on the teaching researches, and the teacher-to-be students shall be required to hold regularly sharing meeting of leading teaching skills, and discuss teaching problems through special topics. All kinds of second class activities can be launched to promote and improve the students' teaching research abilities and practical teaching skills.

The cultivation mode combining professional theory learning and practical application depends on the particularity of teaching skills. Considering the deficiency in cultivating teaching skills of teacher to-be students, this article, based on analyzing characteristics of English teaching, makes a special discussion on the cultivation mode of English teaching skills, which has characteristics of targeted, multiple and high operability, it aims to cultivate the English teacher-to-be students in three stages (namely long, medium and short terms) The long term cultivation mode makes the students form concepts of cultivating skills at the beginning of enrollment, besides, and the combination of professional courses and teaching skills enable the students gasp four basic teaching skills related to English; the cultivation of medium teaching skills make the students grasp certain basic teaching theories and provide them with chances to access to English level and learning needs of primary and middle school students. The medium and long term training enable the students to find problems in practice, therefore, in the short term cultivation, it needs to highlight the mode centered on problems and guided by second class activities, stir the students' enthusiasm of learning teaching skills, further help them think independently and improve the abilities of teaching researches.

\section{CONCLUSION}

This model is created on the basis of employment trend of English teacher-to- be students in local colleges, characteristics of English teaching skills as well learning tasks of the students. 
It is highly targeted and easy to do. Based on theoretical learning and teaching skills practice, supported by multiple activities as well as objective factors as times and spaces considered, it aims to strengthen the wideness, density and depth of skill cultivation so as to place a solid foundation for teaching of English teacher-to-be students in the future and provide a reference for cultivating English teaching skills of English teacher-to-be students in local colleges.

\section{REFERENCES}

[1] Zuo Ju, Researches on Three-Dimensional Cultivation of Professional Skills of English Teachers under New Course Standards [J]. Education and Teaching Research, 2012(10): 22-25.

[2] Huang Feiying, Zhou Zhiyi, Cultivation of Critical Reflection for Teacher-to-be Students: Significance and Methods [J]. Journal of Zhejiang Normal University (Natural Sciences), 2003 (4): 111-114.

[3] Gao Yan, Basic Skills for Modern Teaching [M]. Qingdao: Qingdao Ocean University Press, 2000:50. 